\title{
Clinical Features and Etiology of Musculoskeletal Infection with or without Sepsis in the Emergency Department
}

\author{
Juan Zhang \\ Xiangmin Li \\ Guoqing Huang \\ Aimin Wang \\ Fangjie Zhang (D)
}

Department of Emergency Medicine, Xiangya Hospital, Central South University, Changsha, Hunan, 4I0008, People's Republic of China
Correspondence: Fangjie Zhang Department of Emergency Medicine, Xiangya Hospital, Central South University, No. 87 Xiangya Road, Changsha, Hunan, 410008, People's Republic of China

Tel +86-15I 16256248

Email zhangfj@csu.edu.cn
Background: Musculoskeletal infection (MSKI) is a common reason to seek medical care in the emergency department (ED). We aimed to determine the clinical characteristics and etiology of patients with MSKI in our ED, the characteristics of MSKI with sepsis, and the predictors of death in sepsis patients.

Methods: The study retrospectively analyzed patients with MSKI from April 1, 2017, to March 31, 2021. The patients were divided into non-sepsis and sepsis groups. Clinical data of these patients including their basic information, laboratory results, diagnostic results, and outcomes were collected. Statistical analysis was carried out using GraphPad Prism 5.

Results: In all, 106 patients (70 male, 36 female) were enrolled in this study: 43 MSKI patients with sepsis and 63 MSKI patients without sepsis. Five patients with sepsis died. The patients' age and sex ratio were no significantly different between the sepsis and non-sepsis groups. In the sepsis group, the ratio of rheumatic diseases, diabetes, coronary heart disease, and deep vein thrombosis was significantly different than that in the non-sepsis group (all $\mathrm{p}<0.05)$. Fifty-six patients $(54.37 \%)$ had positive etiology results. Staphylococcus, streptococcus, Klebsiella pneumoniae, Pseudomonas aeruginosa, and Escherichia coli were the most common bacteria found in both groups, but sepsis patients had more Candida albicans infections than non-sepsis patients $(\mathrm{p}=0.0331, \mathrm{p}<0.05)$. The five patients who died in the sepsis group had higher serum levels of creatinine and procalcitonin (PCT). Multivariate logistic regression analyses showed that PCT ( $\mathrm{p}=0.026$; odds ratio, 1.038) was significantly related to mortality.

Conclusion: In MSKI patients, rheumatic diseases, diabetes, coronary heart disease, and deep vein thrombosis are the risk factors for sepsis. Staphylococcus, streptococcus, $K$. pneumoniae, $P$. aeruginosa, and $E$. coli were the most common bacteria in MSKI patients, while MSKI patients with sepsis had more $C$. albicans infections. Elevated PCT was significantly related to death in sepsis patients.

Keywords: musculoskeletal infection, sepsis, emergency department, procalcitonin

\section{Introduction}

Musculoskeletal infection (MSKI) is a common reason to seek medical care in the emergency department (ED). MSKI can present in many forms, depending on the involvement of the various soft-tissue layers, bones, and joints. Infection may manifest as cellulitis, necrotizing fasciitis, pyomyositis, myositis, osteomyelitis, or septic arthritis. It was estimated that MSKI develops in approximately 1.98 million patients every year in the emergency department in the United States, most of whom are diagnosed with cellulitis or a soft-tissue abscess. ${ }^{1}$ Various reasons 
including can lead to MSKI. One of the most important features of treating MSKI is the requirement of a multidisciplinary approach including orthopedic surgeons, infectious disease doctors, radiologists, emergency room physicians, and nurses. ${ }^{2}$ If the MSKI is misdiagnosed and left untreated, the patient's condition can deteriorate to sepsis, septic shock, and even death. ${ }^{3}$

Our Xiangya Hospital of Central South University is a Class-A Grade-3 (top level in China) general hospital under the direct supervision of the National Health Commission and an affiliated hospital of the Central South University directly under the Ministry of Education. It is an important center for clinical care, medical education, and scientific and technological innovation in China. Our hospital services 100-200 million people across several provinces in southern China; therefore, the patients who seek treatment in Xiangya Hospital typically present with serious illnesses.

The aim of the present study was to determine the clinical characteristics and etiology of patients with MSKI in our ED, and to determine the characteristics of MSKI with sepsis and the predictors of death in sepsis patients.

\section{Methods}

The study retrospectively analyzed patients with MSKI who were admitted to and received treatment in the observation unit, rescue unit, and emergency intensive care unit of the Department of Emergency Medicine, Xiangya Hospital of Central South University from April 1, 2017, to March 31, 2021. Patients who were diagnosed with MSKI in the internal medicine clinics, surgical clinics, and dermatology clinics of the Department of Emergency Medicine and received drugs orally at home but did not undergo treatment in the observation unit, rescue unit, and emergency intensive care unit were not included in the study. The study protocols were approved by the ethics committee (No. 202105088) of our hospital and complied with the tenets of the Declaration of Helsinki.

We first divided patients into non-sepsis and sepsis groups in our ED. The sepsis diagnostic criteria was according to the Third International consensus definitions for sepsis and septic shock (sepsis-3). ${ }^{4}$ Subsequently, patients in the sepsis group were divided into deceased and survivor groups. Clinical data of these patients including their basic information (age, sex, comorbidities); diagnostic results, and outcomes were collected. Laboratory results at the time of admission included white blood cell
(WBC), platelet (PLT), and neutrophil (NC) counts and total bilirubin (TBIL), serum creatinine (CR), C-reaction protein (CRP), and procalcitonin (PCT) levels. All patients underwent imaging examination (X-ray, CT, or MRI) of the lesions and lungs. The source of infection was confirmed by blood culture, joint cavity puncture fluid culture, soft tissue wound secretions culture, and intralesional abscess or bone tissue culture. The etiology results were also collected.

\section{Statistical Analysis}

Data were analyzed using GraphPad Prism 5 and SPSS 17.0 software for statistical evaluation. Data are expressed as the mean \pm standard deviation of the mean. Comparisons of measurement data were performed using $t$-tests, whereas comparisons of enumeration data were performed with chi-square tests. Multivariate logistic regression analyses were performed to identify independent factors related to the deceased group. The threshold for entry of variables into the multivariate models was $\mathrm{p}<0.05$. Odds ratios (ORs) and 95\% confidence intervals (CIs) were also calculated. For all analyses, $\mathrm{p}<0.05$ was considered to indicate statistical significance.

\section{Results}

In all, 106 patients (70 male, 36 female) were enrolled in this study: 43 MSKI patients (age: $48.35 \pm 18.5$ years, 31 male) with sepsis and 63 MSKI patients (age: $53.79 \pm 15.22$ years, 39 males) without sepsis. Five patients with sepsis died. The patients' age and sex ratio showed no significant difference between the sepsis and non-sepsis groups (Table 1). However, in the sepsis group, the ratio of rheumatic diseases, diabetes, coronary heart disease, and deep vein thrombosis showed a significant difference than the non-sepsis patients (all $\mathrm{p}<0.05$ ) (Table 1). Furthermore, there were nine patients with septic arthritis in the nonsepsis group and no patient with septic arthritis in the sepsis group $(p=0.0102, p<0.05)$. However, the other MSKI types between the two groups showed no significant difference.

In our study, a total of 56 patients $(54.37 \%)$ had the positive etiology results. The positive ratio in two groups showed no significant difference $(\mathrm{p}=0.4300, \mathrm{p}>0.05)$, but the fungal infection ratio was higher in the sepsis group than the non-sepsis group $(\mathrm{p}=0.0394, \mathrm{p}<0.05)$ (Table 2). Staphylococcus, streptococcus, Klebsiella pneumoniae, Pseudomonas aeruginosa, and Escherichia coli were the most common bacteria in both groups; however, the count 
Table I Baseline Patient Demographics

\begin{tabular}{|c|c|c|c|}
\hline Parameter & $\begin{array}{c}\text { Non- } \\
\text { Sepsis } \\
\text { Patients } \\
(n=63)\end{array}$ & $\begin{array}{c}\text { Sepsis } \\
\text { Patients } \\
(n=43)\end{array}$ & p value \\
\hline Age (years) (range) & $\begin{array}{l}48.35 \pm 18.5 \\
(10-85)\end{array}$ & $\begin{array}{l}53.79 \pm 15.22 \\
(16-83)\end{array}$ & 0.1142 \\
\hline Sex (male) & 39 & 31 & 0.3036 \\
\hline \multicolumn{4}{|l|}{ Comorbidity } \\
\hline Post-trauma or surgery & 16 & 6 & 0.2227 \\
\hline Rheumatic diseases & 10 & 15 & 0.0351 \\
\hline Other tissues or organ infection & 11 & 9 & 1.0000 \\
\hline Tumor & 6 & 2 & 0.4686 \\
\hline Diabetes & 7 & 18 & 0.0004 \\
\hline Blood disease & 3 & 5 & 0.2652 \\
\hline Hypertension & 7 & 11 & 0.0665 \\
\hline Paraplegia & 1 & 0 & 1.0000 \\
\hline Coronary Heart Disease & 2 & 7 & 0.0293 \\
\hline Stroke & 3 & 2 & 1.0000 \\
\hline Liver cirrhosis & 4 & 4 & 0.7124 \\
\hline Chronic Kidney Dysfunction & 4 & 5 & 0.4805 \\
\hline Tuberculosis & 1 & 3 & 0.3013 \\
\hline Thyroid disease & 2 & 0 & 0.5132 \\
\hline Pituitary crisis & 0 & 1 & 0.4057 \\
\hline Peptic ulcer & 2 & 0 & 0.5132 \\
\hline Shingles & 1 & 0 & 1.0000 \\
\hline Deep vein thrombosis & 1 & 7 & 0.0072 \\
\hline Dead patients & 0 & 5 & 0.0095 \\
\hline \multicolumn{4}{|l|}{ Infection } \\
\hline Legs cellulitis & 33 & 25 & 0.6914 \\
\hline Upper extremity cellulitis & 7 & 5 & 1.0000 \\
\hline Foot cellulitis & 7 & 6 & 0.7657 \\
\hline Hand cellulitis & 2 & 1 & 1.0000 \\
\hline Face cellulitis & 5 & 2 & 0.6968 \\
\hline Mouth cellulitis & 1 & 0 & 1.0000 \\
\hline Torso and back cellulitis & 2 & 4 & 0.2202 \\
\hline Neck cellulitis & 2 & 0 & 0.5132 \\
\hline Perineum cellulitis & 0 & 3 & 0.0640 \\
\hline Septic arthritis (total) & 9 & 0 & 0.0102 \\
\hline Knee & 5 & 0 & 0.0789 \\
\hline Ankle & 3 & 0 & 0.2698 \\
\hline Hip & 1 & 0 & 1.0000 \\
\hline Osteomyelitis (total) & 5 & 3 & 1.0000 \\
\hline Lumbar spine & 1 & 0 & 1.0000 \\
\hline Long bones of limbs & 3 & 2 & 1.0000 \\
\hline Wound infection & 1 & 1 & 1.0000 \\
\hline
\end{tabular}

of bacterium in each group was no significantly different (all $\mathrm{p}>0.05$ ). The sepsis group had more cases of Candida albicans infection than the non-sepsis group $(\mathrm{p}=0.0331$, $\mathrm{p}<0.05)$.
Table 2 Laboratory and Etiology Results in Non-Sepsis Patients and Sepsis Patients

\begin{tabular}{|c|c|c|c|}
\hline Parameter & $\begin{array}{l}\text { Non-Sepsis } \\
\text { Patients }(n=63)\end{array}$ & $\begin{array}{l}\text { Sepsis } \\
\text { Patients }(n=43)\end{array}$ & p value \\
\hline \multicolumn{4}{|l|}{ Laboratory results } \\
\hline WBC & $|3.4| \pm 8.862$ & $14.00 \pm 7.934$ & 0.7304 \\
\hline NC & $10.98 \pm 8.603$ & $11.12 \pm 6.665$ & 0.9274 \\
\hline PLT & $292.21 \pm 54.2$ & $133.1 \pm 95.64$ & 0.0001 \\
\hline CRP & $93.85 \pm 54.00$ & $158.91 \pm 17.4$ & 0.0018 \\
\hline PCT & $3.644 \pm 7.908$ & $20.54 \pm 27.17$ & 0.0001 \\
\hline \multicolumn{4}{|l|}{ Etiology results } \\
\hline Positive patients (\%) & 31 (49.2\%) & $25(58.13 \%)$ & 0.4300 \\
\hline Gram stain $^{+}$bacterium & 23 & 9 & 0.0939 \\
\hline Gram $^{-}$bacterium & 21 & 20 & \\
\hline Bacterium & 44 & 29 & 0.0394 \\
\hline Fungus & 1 & 6 & \\
\hline Total & 45 & 35 & \\
\hline Methicillin-sensitive & 5 & 4 & 1.0000 \\
\hline Staphylococcus aureus (MSSA) & & & \\
\hline Methicillin-resistant & 3 & 2 & 1.0000 \\
\hline Staphylococcus aureus (MRSA) & & & \\
\hline Staphylococcus hominis & 1 & 1 & 1.0000 \\
\hline Staphylococcus caprae & 1 & 0 & 1.0000 \\
\hline Staphylococcus ludenica & 1 & 0 & 1.0000 \\
\hline Staphylococcus haemolyticus & 1 & 0 & 1.0000 \\
\hline Streptococcus (total) & 5 & 6 & 0.5209 \\
\hline Pyogenic streptococcus & 2 & 2 & 1.0000 \\
\hline Streptococcus dysgalactiae & 2 & 3 & 0.6488 \\
\hline Streptococcus agalactiae & 1 & 1 & 1.0000 \\
\hline Candida (total) & 1 & 5 & 0.0811 \\
\hline Candida albicans & 0 & 4 & 0.0331 \\
\hline Candida glabrata & 0 & 1 & 0.4375 \\
\hline Candida tropicalis & 1 & 0 & 1.0000 \\
\hline Klebsiella pneumoniae & 4 & 7 & 0.1969 \\
\hline Pseudomonas aeruginosa & 7 & 1 & 0.0735 \\
\hline Acinetobacter baumannii & 0 & 2 & 0.1981 \\
\hline Escherichia coli & 5 & 1 & 0.2234 \\
\hline Enterobacter cloacae & 1 & 1 & 1.0000 \\
\hline Bacillus cereus & 0 & 1 & 0.4375 \\
\hline Proteus mirabilis & 1 & 0 & 1.0000 \\
\hline Cryptobacillus hemolyticus & 0 & 1 & 0.4375 \\
\hline Enterococcus faecalis & 1 & 1 & 1.0000 \\
\hline Enterococcus avium & 1 & 0 & 1.0000 \\
\hline Enterococcus raffinose & 1 & 0 & 1.0000 \\
\hline Enterococcus pluvialis & 1 & 0 & 1.0000 \\
\hline Prevotella Buccalis & 1 & 0 & 1.0000 \\
\hline Prevotella oris & 1 & 0 & 1.0000 \\
\hline Eikenella corrodens & 1 & 0 & 1.0000 \\
\hline Stenotrophomonas maltophilia & 1 & 0 & 1.0000 \\
\hline Serratia marcescens & 1 & 0 & 1.0000 \\
\hline Fusobacterium navicularis & 0 & 1 & 0.4375 \\
\hline Veronococcus minor & 0 & 1 & 0.4375 \\
\hline Aeromonas hydrophila & 1 & 0 & 1.0000 \\
\hline Micromonas parvum & 1 & 0 & 1.0000 \\
\hline Cyanobacterium marneffei & 0 & 1 & 0.4375 \\
\hline
\end{tabular}


Table 3 presents the basic information of deceased sepsis patients. Table 4 details different outcomes in sepsis patients. Five patients (11.63\%, age: $57.40 \pm 14.12$ years, 4 male) died in the sepsis group, and 38 patients (age: 53.32 \pm 15.47 years, 27 male) were alive. Patients who died had higher levels of serum $\mathrm{CR}$ and PCT than the surviving patients $(\mathrm{p}=0.0421$ and $\mathrm{p}=0.0001$, respectively). There were no significant differences with respect to age; sex; comorbidity; WBC, NC, and PLT counts, TBIL, and CRP levels (all $\mathrm{p}>0.05$ ) when compared between the deceased and alive patients.

To determine the independent factors related to the deceased patient group, multivariate logistic regression analyses were performed. The threshold for entry of variables into the multivariate models was $p<0.05$. The results of multivariate logistic regression are shown in Table 5. We found that PCT levels ( $p=0.026$; OR, 1.038) was significantly related to death.

\section{Discussion}

The clinical manifestations of MSKI range from isolated osteomyelitis, septic arthritis to systemic multisite infections with several complications, and septic shock. ${ }^{5}$ In our study, most MSKI patients were diagnosed with soft tissue
Table 4 Comparison of Patients with Different Outcomes with Sepsis

\begin{tabular}{|l|l|l|l|}
\hline & Deceased $(\mathbf{n}=5)$ & Survivors $(\mathbf{n}=\mathbf{3 8})$ & P value \\
\hline Age (years) & $57.40 \pm 14.12$ & $53.32 \pm 15.47$ & 0.5789 \\
Sex (male) & 4 & 27 & 1.0000 \\
Comorbidity & $2.6 \pm 1.517$ & $2.154 \pm 1.387$ & 0.5059 \\
WBC & $13.68 \pm 9.842$ & $14.04 \pm 7.808$ & 0.9941 \\
NC & $12.72 \pm 9.506$ & $10.91 \pm 6.346$ & 0.6249 \\
PLT & $107.8 \pm 64.22$ & $136.4 \pm 99.19$ & 0.0779 \\
TBIL & $11.54 \pm 8.190$ & $24.19 \pm 16.79$ & 0.2899 \\
Cr & $197.8 \pm 78.49$ & $167.9 \pm 101.1$ & 0.0421 \\
CRP & $194.1 \pm 151.3$ & $153.4 \pm 113.2$ & 0.0884 \\
PCT & $49.81 \pm 33.97$ & $16.11 \pm 23.56$ & 0.0001 \\
\hline
\end{tabular}

infection, especially cellulitis, while the bone and joint infection rate was relatively low. Our results are consistent with those of previous studies wherein male subjects were more susceptible to cellulitis, osteomyelitis, and septic arthritis than female subjects. Cellulitis is an acute, diffuse purulent inflammation of the dermis and subcutaneous tissues. ${ }^{6}$ A previous study confirmed that cellulitis is one of the most common form of skin and soft tissue infection leading to more than 600,000 hospitalizations each year, 1 and more than 9 million patients always along with cutaneous abscess. ${ }^{7}$ Osteoarticular infection including acute

Table 3 Deceased Patients' Basic Information

\begin{tabular}{|c|c|c|c|c|c|c|}
\hline $\begin{array}{l}\text { Deceased } \\
\text { Patients }\end{array}$ & Sex & $\begin{array}{l}\text { Age } \\
\text { (Years) }\end{array}$ & Comorbidity & Manifestation & Imaging & $\begin{array}{l}\text { Simultaneous } \\
\text { Infection }\end{array}$ \\
\hline I & Male & 69 & $\begin{array}{l}\text { Rheumatoid } \\
\text { arthritis, coronary } \\
\text { heart disease, } \\
\text { diabetes, } \\
\text { hypertension, }\end{array}$ & $\begin{array}{l}\text { Body edema for I month, fever for } \\
2 \text { days, unconscious for } 4 \mathrm{~h} \text {, and } \\
\text { required cardiopulmonary } \\
\text { resuscitation in the ED. }\end{array}$ & $\begin{array}{l}\text { CT showed a large area of } \\
\text { soft tissue infection in the } \\
\text { abdomen and pressure ulcer } \\
\text { on the buttocks }\end{array}$ & No \\
\hline 2 & Female & 65 & $\begin{array}{l}\text { Diabetes, coronary } \\
\text { heart disease, }\end{array}$ & $\begin{array}{l}\text { Facial swelling and pain for } 7 \text { days, } \\
2 \text { days after cardiopulmonary } \\
\text { resuscitation }\end{array}$ & $\begin{array}{l}\text { CT showed facial cellulitis } \\
\text { and pneumonia }\end{array}$ & Pneumonia \\
\hline 3 & Male & 50 & $\begin{array}{l}\text { Coronary heart } \\
\text { disease, pituitary } \\
\text { crisis, deep vein } \\
\text { thrombosis }\end{array}$ & $\begin{array}{l}\text { Left lower limb pain for } 3 \text { months, } \\
\text { fever for half a month }\end{array}$ & $\begin{array}{l}\text { MRI showed whole left } \\
\text { lower limb cellulitis }\end{array}$ & No \\
\hline 4 & Male & 67 & $\begin{array}{l}\text { Diabetes, chronic } \\
\text { renal impairment, } \\
\text { deep vein } \\
\text { thrombosis, }\end{array}$ & $\begin{array}{l}\text { Ulcer and swelling of the right } \\
\text { lower limb for } 20 \text { days }\end{array}$ & $\begin{array}{l}\text { MRI showed right lower limb } \\
\text { cellulitis and pressure ulcer }\end{array}$ & No \\
\hline 5 & Male & 36 & None & $\begin{array}{l}\text { Pain and fever all over the body } \\
\text { after fighting for } 10 \text { days }\end{array}$ & $\begin{array}{l}\text { MRI showed right upper limb } \\
\text { and left buttock soft tissue } \\
\text { infection }\end{array}$ & No \\
\hline
\end{tabular}


Table 5 Multivariate Logistic Regression Models for Independent Factors Related to Death of Septic Patients

\begin{tabular}{|l|l|l|l|}
\hline & $\mathbf{P}$ & OR & $\mathbf{9 5 \%} \mathbf{C l}$ \\
\hline $\mathrm{Cr}$ & 0.603 & 1.002 & $0.994-1.010$ \\
$\mathrm{PCT}$ & 0.026 & 1.038 & $1.005-1.073$ \\
\hline
\end{tabular}

osteomyelitis and septic arthritis is an uncommon disease among adults. In Spain, the incidence was 3.85 cases/ 100,000 people per year, and most commonly occurred in men, with an in-hospital mortality rate of $1.72 \%{ }^{8}$ The incidence of acute septic arthritis varies from 2 to 6 cases/ 100,000 people per year, with the highest incidence occurring in people with older than 55 years. ${ }^{9}$

In our study, $40.57 \%$ MSKI patients met the diagnostic criteria, and MSKI patients with sepsis had a relatively higher rate of comorbidity with rheumatic diseases, diabetes, coronary heart disease, and deep vein thrombosis (DVT). Sepsis results from the host response to infection, and it was well known that rheumatic diseases and diabetes lead to an abnormal immune response including chronic inflammation or metabolic abnormalities, which further worsen the host response against infections. ${ }^{10,11}$ Coronary heart disease and DVT could result in chronic edema, and chronic edema is a risk factor for cellulitis and recurrent cellulitis. ${ }^{12}$ Furthermore, both coronary heart disease and DVT were confirmed as risk factors for sepsis. $^{13}$

The management of MSKI depends on quick and accurate recognition of pathogenic microorganisms and a thorough identification of the infection site and tissue involved. ${ }^{5}$ The pathogenic microorganisms of septic arthritis in adults may be closely related to the patient's current medical history, family history, physical condition, and drug abuse, but the pathogens are still mainly Staphylococcus aureus, streptococcus, and gram-negative rods. ${ }^{14}$ In the case of cellulitis, most identified pathogenic microorganisms are $\beta$-hemolytic streptococcus and S. aureus. ${ }^{15}$ Our results are also in line with those of the previous studies, wherein staphylococcus and streptococcus were the most common pathogenic organisms. However, in the sepsis patients in our study, the ratio of fungal infections was higher than that in the non-sepsis patients. Fungal MSKI infections are complex infections that are rarely encountered in routine clinical practice. ${ }^{16}$ The most common fungal genus causing MSKI is Candida, which comprises at least 15 distinct species; of these, Candida albicans is by far the most common, ${ }^{16}$ Our study also showed the same result.

In our study, sepsis patients had higher levels of PCT and CRP than non-sepsis patients, while the WBC and NC counts were not significantly elevated in the sepsis patients. Our study showed that deceased patients with sepsis had higher levels of serum $\mathrm{Cr}$ and $\mathrm{PCT}$, and the multivariate logistic regression indicated that higher PCT had a predictive value for mortality. PCT, CRP, WBC, and NC were all used as traditional infection biomarkers. Generally, PCT levels become detectable at 4 $\mathrm{h}$ and peak between 12 and $24 \mathrm{~h}$ after fungal or bacterial infection. PCT levels are typically not elevated during viral infections. ${ }^{17}$ Comparatively, CRP typically begins to elevate within $6 \mathrm{~h}$ of a stimulus and peak later than PCT, between 24 and $72 \mathrm{~h}^{17}$ McMichael et al reported that PCT, CRP, and erythrocyte sedimentation rate (ESR) performed reasonably well for the detection of MSKI, while WBC count was not predictive of MSKI. ${ }^{18}$ Woo et al also confirmed that CRP and PCT had better predictive function for sepsis than WBC count. ${ }^{19}$ In a multicenter trial, sepsis patients received either PCT-guided discontinuation of antimicrobials or standard of care. The results indicated that PCT guidance was effective in reducing infection-associated adverse events and 28-day mortality. ${ }^{20}$

\section{Limitations}

Our study has some limitations. First, we just performed a retrospective study and did not analyze the relationship between the time of antibiotic use and prognosis. Second, we did not analyze the diagnostic threshold of PCT and CRP for sepsis. Last, owing to the low incidence of septic arthritis and osteomyelitis, most cases included in the study involved soft tissue infection.

\section{Conclusions}

In MSKI patients, rheumatic diseases, diabetes, coronary heart disease, and DVT are risk factors for sepsis. Staphylococcus, streptococcus, K. pneumoniae, $P$. aeruginos $a$, and $E$. coli were the most common bacteria in MSKI patients, while sepsis patients had more Candida albicans infections. Elevated PCT levels were significantly related to death in sepsis patients.

\section{Data Sharing Statement}

All data generated or analyzed during this study are included in the manuscript. 


\section{Consent for Publication}

All authors have read and approved the manuscript. The data in the present study were retrospective and anonymous, and the requirement for patients informed consent was therefore waived.

\section{Author Contributions}

All authors contributed to data analysis, drafting, or revising the article; have agreed on the journal to which the article will be submitted; provided final approval of the version to be published; and agreed to be accountable for all aspects of the work.

\section{Funding}

This work was supported by the National Natural Science Foundation of China (No. 81501923) and the Rui E (Ruiyi) Emergency Medical Research Special Funding Project (No. R2019007) and 2021 Investment Project of Development and Reform Commission of Hunan Province (No.212) .

\section{Disclosure}

The authors declare that there are no conflicts of interest.

\section{References}

1. McCaig LF, Nawar EW. National hospital ambulatory medical care survey: 2004 emergency department summary. Adv Data. 2006;372:1-29.

2. Dolitsky R, DePaola K, Fernicola J, Collins C. Pediatric musculoskeletal infections. Pediatr Clin North Am. 2020;67(1):59-69.

3. Collazos J, de la Fuente B, de la Fuente J, et al. Factors associated with sepsis development in 606 Spanish adult patients with cellulitis. $B M C$ Infect Dis. 2020;20(1):211.

4. Singer M, Deutschman CS, Seymour CW, et al. The third international consensus definitions for Sepsis and Septic Shock (Sepsis-3). JAMA. 2016;315(8):801-810.
5. Rosenfeld SB, Copley LA, Mignemi M, An T, Benvenuti M, Schoenecker J. Key concepts of musculoskeletal infection. Instr Course Lect. 2017;66:569-584.

6. Phoenix G, Das S, Joshi M. Diagnosis and management of cellulitis. BMJ. 2012;345:e4955.

7. Gunderson CG. Cellulitis: definition, etiology, and clinical features. Am J Med. 2011;124(12):1113-1122.

8. Lopez DPP, Guerrero EA. Incidence and mortality of osteomielitis in Spain according to the basic minimum data set. Med Clin (Barc). 2019;153(11):418-423.

9. Ben-Chetrit E, Zamir A, Natsheh A, Nesher G, Wiener-Well Y, Breuer GS. Trends in antimicrobial resistance among bacteria causing septic arthritis in adults in a single center: a 15 -years retrospective analysis. Intern Emerg Med. 2020;15(4):655-661.

10. Thompson K, Venkatesh B, Finfer S. Sepsis and septic shock: current approaches to management. Intern Med J. 2019;49(2):160-170.

11. Costantini E, Carlin M, Porta M, Brizzi MF. Type 2 diabetes mellitus and sepsis: state of the art, certainties and missing evidence. Acta Diabetol. 2021;10:1-3.

12. Webb E, Neeman T, Bowden FJ, Gaida J, Mumford V, Bissett B. Compression therapy to prevent recurrent cellulitis of the leg. $N$ Engl J Med. 2020;383(7):630-639.

13. Suarez DLRA, Gilsanz F, Maseda E. Epidemiologic trends of sepsis in western countries. Ann Transl Med. 2016;4(17):325.

14. Dubost JJ, Couderc M, Tatar Z, et al. Three-decade trends in the distribution of organisms causing septic arthritis in native joints: single-center study of 374 cases. Joint Bone Spine. 2014;81 (5):438-440.

15. Raff AB, Kroshinsky D. Cellulitis: a review. JAMA. 2016;316 (3):325-337.

16. Henry MW, Miller AO, Walsh TJ, Brause BD. Fungal musculoskeletal infections. Infect Dis Clin North Am. 2017;31(2):353-368.

17. Covington EW, Roberts MZ, Dong J. Procalcitonin monitoring as a guide for antimicrobial therapy: a review of current literature. Pharmacotherapy. 2018;38(5):569-581.

18. McMichael BS, Nickel AJ, Christensen EW, et al. Discriminative accuracy of procalcitonin and traditional biomarkers in pediatric acute musculoskeletal infection. Pediatr Emerg Care. 2020.

19. Woo A, Oh DK, Park CJ, Hong SB. Monocyte distribution width compared with C-reactive protein and procalcitonin for early sepsis detection in the emergency department. PLoS One. 2021;16(4): e0250101.

20. Kyriazopoulou E, Liaskou-Antoniou L, Adamis G, et al. Procalcitonin to reduce long-term infection-associated adverse events in Sepsis. a randomized trial. Am J Respir Crit Care Med. 2021;203 (2):202-210.
International Journal of General Medicine

\section{Publish your work in this journal}

The International Journal of General Medicine is an international, peer-reviewed open-access journal that focuses on general and internal medicine, pathogenesis, epidemiology, diagnosis, monitoring and treatment protocols. The journal is characterized by the rapid reporting of reviews, original research and clinical studies across all disease areas. The manuscript management system is completely online and includes a very quick and fair peer-review system, which is all easy to use. Visit http://www.dovepress.com/ testimonials.php to read real quotes from published authors. 